\title{
Simulation of hydrological processes in the Simiyu River, tributary of Lake Victoria, Tanzania
}

\author{
Justus Rwetabula ${ }^{1,2 *}$, Florimond De Smedt ${ }^{1}$ and Menahem Rebhun ${ }^{3}$ \\ ${ }^{1}$ Department of Hydrology and Hydraulic Engineering, Vrije Universiteit Brussel, Brussels, Belgium \\ ${ }^{2}$ Ministry of Water, Dar Es Salaam, Tanzania \\ ${ }^{3}$ Environmental and Water resources Engineering, Technion Israel Institute of Technology, Haifa, Israel
}

\begin{abstract}
A spatially-distributed hydrologic model (WetSpa) is used to simulate hydrologic processes in the Simiyu River, a tributary of Lake Victoria, Tanzania. The model combines digital maps of topography, land-use and soil texture with observed daily meteorological time series to predict discharge hydrographs and spatial distribution of hydrologic parameters in the basin. The model was calibrated using 3 years of daily observed discharge measured at the mouth of the river at Lake Victoria. The estimated average travel time of the runoff to the outlet of the basin is about 2.4 days and a maximum of 8 days for the most remote areas. The model results show that the surface runoff and interflow provide, respectively, $38.6 \%$ and $61.4 \%$ of the total discharge, while the contribution of groundwater drainage is about nil. The absence of groundwater drainage is likely due to the high evaporative demand of the atmosphere, which accounts for about $90 \%$ of the total precipitation being lost by evapotranspiration. The annual water balance estimated with the model reveals that the total outflow to Lake Victoria is about $475 \times 10^{6} \mathrm{~m}^{3}$ per year, which occurs mainly in the wet seasons, i.e. from March to May and from November to January. The discharge volume produced by agricultural land amounts to about $43 \times 10^{6} \mathrm{~m}^{3}$ and may carry agrochemicals to Lake Victoria.
\end{abstract}

Keywords: Hydrologic modelling, Simiyu River, Lake Victoria, WetSpa, Tanzania

\section{Introduction}

Lake Victoria is the largest freshwater lake in Africa, and one of the major sub-basins within the Nile basin, sharing its resources with Tanzania, Kenya and Uganda (Ningu, 2000; Phoon et al., 2004). The water quality of Lake Victoria has been declining due to point and non-point pollution sources from domestic, industrial and agricultural activities. Pollution from agriculture consists mainly of fertilisers and pesticides (Scheren et al., 2000). To address these problems, the riparian countries established the Lake Victoria Environmental Management Project (LVEMP), a World Bank funded project, which became operational in 1997, aiming at rehabilitation of the degraded lake ecosystem.

The main processes affecting the fate of the pollutants include surface runoff, erosion and sediment transport, and chemical, biological, and biochemical interactions within the soil-plant-water system. The hydrological cycle has an especially prominent role in the functioning of these processes. This means that the task of quantifying, or modelling, pollutant loads must include consideration of hydrology, water and soil chemistry, micro-and macro-biology, and many other disciplines (Jolankai et al., 1999).

The main contributions to the pollution of Lake Victoria from Tanzania are the Mara, Kagera, and Simiyu basins (Crul, 1995). The Simiyu basin is considered to be one of the main contributors to the deterioration of Lake Victoria, because it is relatively large (10 $\left.800 \mathrm{~km}^{2}\right)$, with many

\footnotetext{
* To whom all correspondence should be addressed.

핑 +255753277247;

e-mail: irwetabu2@yahoo.com

Received 14 August 2011; accepted in revised form 9 July 2012.
}

agricultural activities using agrochemicals (Ningu, 2000), and generating a high yield of sediments (Lugomela and Machiwa, 2002). Pollution transport of the Simiyu River to Lake Victoria is clearly associated with seasonal river flow patterns. Higher chemical concentrations appear during high flows indicating that the majority of contaminants is released from agricultural fields during storm events (Lugomela and Machiwa, 2002; Henry and Kishimba, 2003; Rwetabula et al., 2006). Chemicals are mainly transported in dissolved or particulate form by surface runoff and channel flow. Hence, proper water quality management cannot be initiated without a clear understanding of the hydrological processes in the Simiyu River basin. Therefore, models capable of predicting flow and water quality are needed to predict the effects of land use and waste management for decision making.

In this study, a modelling approach is described using remotely-sensed data, GIS tools, and the WetSpa hydrological model to predict the Simiyu River discharge and the hydrological characteristics within the basin. The distributed hydrological model WetSpa was originally developed by Wang et al. (1996) and adopted for flood prediction by De Smedt et al. (2000) and Liu and De Smedt (2004a).The model is simple to use, needs very limited input parameters, and generally performs well in reproducing river discharges (Liu and De Smedt, 2004a; Bahremand et al., 2005). WetSpa is also very suited for basins with limited data, because it contains a large set of preset physical and hydrological parameters that are not site-specific. It has been applied in tropical environments by Liu et al. (2005) and Nurmohamed et al. (2006), for analysing effects of climate changes on stream flow by Gebremeskel et al. (2005), and for prediction of phosphorus transport by Liu et al. (2006). However, it has not been tested in an ephemeral/intermittent river environment. Hence, the purpose of this study is to apply the WetSpa hydrological model to simulate hydrological 
processes in the Simiyu River in order to predict the amount of discharge to Lake Victoria. In a subsequent study, results of the model together with contaminant concentrations will be used to predict the chemical loads generated in the Simiyu basin and deposited in Lake Victoria. The paper is organised as follows: introduction; methods, with WetSpa model overview and description of Simiyu basin and data collection; model application including model input; model calibration and discussion of model results; and conclusions.

\section{Methods}

\section{WetSpa model}

WetSpa is a grid-based distributed hydrological model for predicting the water and energy transfer in soil, plants and atmosphere on a regional or basin scale, as proposed by Wang et al. (1996), and further extended and applied by other researchers for flood prediction and stream flow simulation (De Smedt et al., 2000, 2004; Liu et al., 2002; Liu and De Smedt, 2004b; Bahremand et al., 2005). Hydrological components considered in the model are precipitation, interception, depression storage, surface runoff, infiltration, evapotranspiration, percolation, interflow, groundwater flow, and water balance in the root zone and the saturated zone. Running of the model and parameter selection are explained in the user manual (Liu and De Smedt, 2004a).

The water balance in the root zone is important, because soil wetness is a key factor controlling the amount of surface runoff, interflow and groundwater recharge. The water balance for each grid cell in the root zone is computed as:

$$
D \frac{\partial \theta}{\partial t}=P-I-S-E-F-R
$$

where:

$D$ is root depth [L]

$\theta$ is soil moisture content $\left[\mathrm{L}^{3} \cdot \mathrm{L}^{-3}\right]$ in the root zone

$t$ is time [T], $P$ precipitation rate $\left[{\left.\mathrm{L} \cdot \mathrm{T}^{-1}\right]}^{-1}\right.$

$I$ is initial abstraction including interception and depression storage $\left[\mathrm{L}^{-1}{ }^{-1}\right]$

$S$ is surface runoff $\left[{\left.\mathrm{L} \cdot \mathrm{T}^{-1}\right]}^{-1}\right.$

$E$ is evapotranspiration $\left[\mathrm{L} \cdot \mathrm{T}^{-1}\right]$

$F$ is interflow $\left[\mathrm{L} \cdot \mathrm{T}^{1}\right]$

$R$ is recharge to groundwater $\left[\mathrm{L} \cdot \mathrm{T}^{-1}\right]$

Interception depends on storm intensity and vegetation and depression storage and is controlled by slope, soil type and land-use. Water loss by interception is returned to the atmosphere through evaporation, while water held in depressions either evaporates or contributes afterwards to infiltration. The remaining rainfall is separated into runoff and infiltration, depending on land cover, soil type, slope, and antecedent moisture content of the soil. The infiltrated part of the rainfall may contribute to soil moisture in the root zone, move laterally as interflow, or percolate further down as groundwater recharge depending on the water-holding capacity of the soil. Evaporation from the soil and transpiration from vegetation is regulated by the evaporative demand of the atmosphere, soil and plant characteristics, and soil wetness.

Surface runoff is computed using a soil moisture related runoff coefficient:

$$
S=c_{r}(P-I)\left(\theta / \theta_{s}\right)^{\alpha}
$$

where:

$\theta_{s}$ is saturated soil moisture content $\left[\mathrm{L}^{3} \cdot \mathrm{L}^{-3}\right]$

$C_{r}$ is potential runoff coefficient [-] depending on slope, land-use and soil type

$\alpha$ is an empirical parameter [-] that expresses the effect of rainfall intensity on runoff generation:

$$
\alpha=\max \left[1, K_{r u n}+\left(1-K_{r u n}\right) P / P_{0}\right]
$$

with:

$$
\begin{aligned}
& K_{\text {run }} \text { a runoff coefficient [-] larger than one } \\
& P_{0}\left[\mathrm{~L} \cdot \mathrm{T}^{-1}\right] \text { a precipitation intensity scaling factor }
\end{aligned}
$$

The value of $\alpha$ approaches $K_{r u n}$ for low rainfall intensities, resulting in less surface runoff, and approaches 1 for high rainfall intensities resulting in more runoff proportional to the relative soil water content $\theta / \theta_{s}$. Values for the potential runoff coefficient, $c_{r}$, were collected and compiled from literature (Dunne, 1978; Chow et al., 1988; Browne, 1990; Mallants and Feyen, 1994) and linked to slope, soil type and land-use classes using lookup tables (Liu and De Smedt, 2004a). Evapotranspiration from soil and vegetation is calculated using the relationship developed by Thornthwaite and Mather (1955) as a function of potential evapotranspiration, vegetation type, stage of growth and soil moisture content:

$$
\begin{cases}E=0 & \text { if } \theta<\theta_{w p} \\ E=\left(c_{v} K_{e p} E_{p}-I\right)\left(\frac{\theta-\theta_{w p}}{\theta_{f c}-\theta_{w p}}\right) & \text { if } \theta_{w p} \leq \theta \leq \theta_{f c} \\ E=c_{v} K_{e p} E_{p}-I & \text { if } \theta>\theta_{f c}\end{cases}
$$

where:

$c_{v}$ is a vegetation coefficient [-] which varies throughout the year depending on growing stage and vegetation type $K_{e p}$ is a correction factor [-] for adjusting potential evaporation $E_{p}\left[\mathrm{~L} \cdot \mathrm{T}^{1}\right]$

$\theta_{w p}$ is soil moisture content $\left[\mathrm{L}^{3} \cdot \mathrm{L}^{-3}\right]$ at permanent wilting point

$\theta_{f c}$ is soil moisture content $\left[\mathrm{L}^{3} \cdot \mathrm{L}^{-3}\right]$ at field capacity

When the soil moisture is lower than the wilting point $\left(\theta<\theta_{w p}\right)$, evapotranspiration is still possible by capillary rise from the groundwater, which is controlled by the groundwater storage $G$ [L] and a scaling parameter $G_{m}[\mathrm{~L}]$ :

$$
E_{G}=\left(c_{v} K_{e p} E_{p}-I\right)\left(G / G_{m}\right) \quad \text { if } \theta<\theta_{w p}
$$

where:

$$
E_{G}\left[\mathrm{~L} \cdot \mathrm{T}^{-1}\right] \text { is evaporation from groundwater }
$$

The rate of percolation $R$ or groundwater recharge is derived by the Brooks and Corey relationship (Eagleson, 1978; Famiglietti and Wood, 1994):

$$
R=K(\theta)=K_{S}\left(\frac{\theta-\theta_{r}}{\theta_{S}-\theta_{r}}\right)^{3+2 / B}
$$

where:

$K(\theta)$ is the unsaturated hydraulic conductivity $\left[\mathrm{L}^{-1} \mathrm{~T}^{-1}\right]$

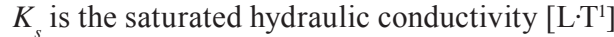

$\theta_{r}^{s}$ is the residual soil moisture content $\left[\mathrm{L}^{3} \cdot \mathrm{L}^{-3}\right]$

$B$ is the soil pore size distribution index [-]

Interflow is assumed to occur when soil moisture is higher than field capacity and is determined as a function of hydraulic 
conductivity, soil moisture content, slope angle and root depth:

$$
F=D S_{0} K_{i} K(\theta) / W
$$

where:

$S_{0}$ is surface slope $\left[\mathrm{L} \cdot \mathrm{L}^{-1}\right]$

$W$ is the cell width [L]

$K_{i}$ [-]is a scaling parameter to adjust the horizontal hydraulic conductivity in the upper soil layer.

Groundwater flow is estimated using a simplified lumped linear reservoir on small GIS-derived sub-basin scale, while a nonlinear relationship between groundwater flow and groundwater storage is optional in the model (Wittenberg 1999; Liu and De Smedt, 2004a):

$$
Q_{G}=K_{g} G
$$

where:

$Q_{G}\left[\mathrm{~L} \cdot \mathrm{T}^{-1}\right]$ is groundwater drainage

$K_{g}\left[\mathrm{~T}^{-1}\right]$ is baseflow recession constant

$G[\mathrm{~L}]$ is groundwater storage, which can be obtained from the groundwater balance:

$$
\frac{\partial G}{\partial t}=R-Q_{G}-E_{G}
$$

Surface runoff, interflow, and groundwater drainage generated at any location in the basin are routed to the basin outlet by the diffusive waveform approximation of the St. Venant equations:

$$
\frac{\partial Q}{\partial t}=d \frac{\partial^{2} Q}{\partial x^{2}}-c \frac{\partial Q}{\partial x}
$$

where:

$Q$ is discharge $\left[\mathrm{L}^{3} \cdot \mathrm{T}^{-1}\right]$ at location $x$ and time $t$

$x$ is the distance $[\mathrm{L}]$ along the flow path

$c$ is the wave celerity [L-T'- $]$

$d$ is the wave dissipation coefficient $\left[\mathrm{L}^{2} \cdot \mathrm{T}^{-1}\right]$

The wave celerity $c$ and dissipation coefficient $d$ depend on the flow velocity, flow depth, and terrain characteristics: $c=(5 / 3)$ $v$, and $d=(v H) /\left(2 S_{0}\right)$ (Henderson, 1966), where $v$ is the flow

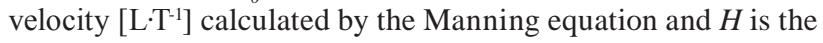
hydraulic radius $[\mathrm{L}]$ or average flow depth.

An approximate solution of Eq. (10), in the form of an instantaneous unit hydrograph (IUH), relating the discharge at the end of flow path to the available runoff at any upstream location, is given as (De Smedt et al., 2000; Liu et al., 2003):

$$
U(t)=\frac{1}{\sigma \sqrt{2 \pi t^{3} / t_{0}^{3}}} \exp \left[-\frac{\left(t-t_{0}\right)^{2}}{2 \sigma^{2} t / t_{0}}\right]
$$

and

$$
\mathrm{Q}(\mathrm{t})=\int_{\mathrm{A}} \int_{0}^{\mathrm{t}}(\mathrm{P}-\mathrm{I})(\tau) \mathrm{U}(\mathrm{t}-\tau) \mathrm{d} \tau \mathrm{dA}
$$

where:

$U(t)$ is flow path unit response function $\left[\mathrm{T}^{-1}\right]$, which routes excess water from each grid cell to the basin outlet or any downstream convergent point

$t_{o}$ is average travel time to the outlet along the flow path [T] $\sigma$ is the standard deviation of the flow time [T]

$Q(t)$ is the outlet flow hydrograph $\left[\mathrm{L}^{3} \cdot \mathrm{T}^{-1}\right]$

$\tau$ is the time delay [T]

$A$ is the drainage area of the basin $\left[\mathrm{L}^{2}\right]$

Parameters $t_{o}$ and $\sigma$ are spatially distributed and can be obtained by integration along the topographically determined flow paths as a function of the flow celerity $c$ and dissipation coefficient $d$ as suggested by De Smedt et al. (2000).

$$
\left\{\begin{array}{l}
t_{o}=\int c^{-1} d x \\
\sigma=\sqrt{\int 2 d c^{-3} d x}
\end{array}\right.
$$

Hence, the flow routing involves the tracking of surface runoff and interflow along topographically determined flow paths, such that a response function is obtained for every grid cell to the basin outlet or any other downstream convergence point. The routing response serves as an instantaneous unit hydrograph and the total discharge is obtained by convolution of the flow response from all grid cells using Eqs. (11) and (12). The total river discharge at the downstream convergence point is obtained by superimposing all contributions from every grid cell and the groundwater outflow generated in each sub-basin.

The only inputs to the model are digital data of elevation, soil type, and land-use in raster format, and observed time series of precipitation and potential evaporation.

Observed river discharge time series are optional for model calibration. Most model parameters, including all spatially distributed basin properties, are automatically derived from the basic input data using a database included in the WetSpa model.

The general procedure is shown in Fig. 1. All parameters provided in this database are physically based and not sitespecific. Hence, this makes the model ideally suited for applications where comprehensive field data is lacking. The basic

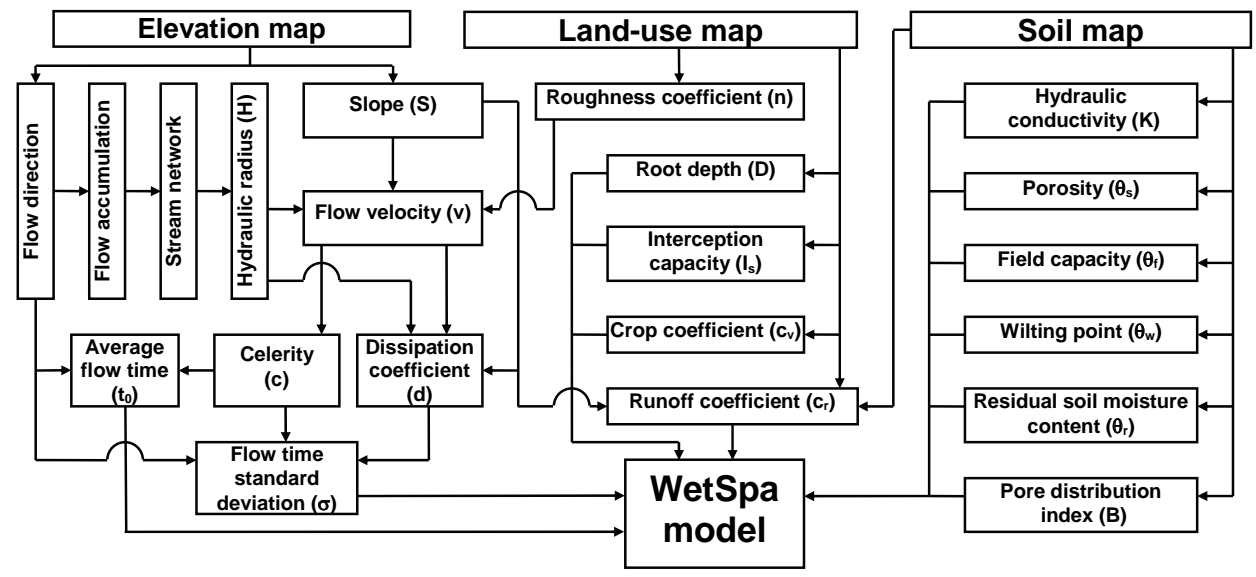

Figure 1

Schematic representation of WetSpa procedures to derive spatial model parameters from topography, soil texture, and land-use maps 


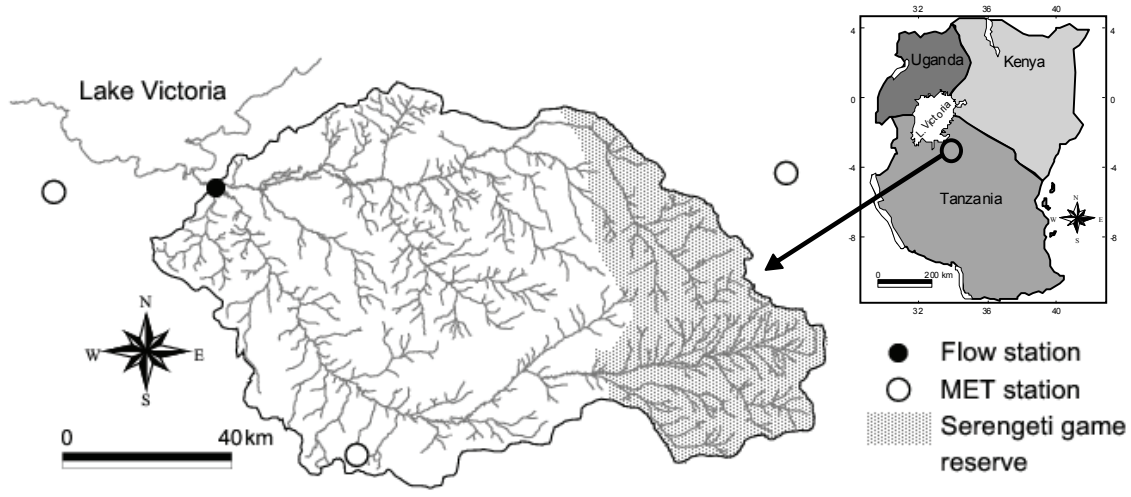

Figure 2

Schematic representation of the Simiyu basin, showing regional location, basin boundaries, main rivers, and location of the meteorological stations and river gauging station

outputs of the model are predicted hydrographs at the basin outlet or at any selected sub-basin outlet. Other outputs are spatial distributions of the simulated hydrological parameters in the form of GIS maps.

\section{Simiyu basin and data collection}

The Simiyu basin is located southeast of Lake Victoria in north Tanzania (Fig. 2), and covers an area of about $10800 \mathrm{~km}^{2}$. The topography is generally flat with small undulating hills. The elevation in the basin ranges from about 1100 to $2000 \mathrm{~m}$. The Serengeti national park/game reserve is situated in the east in the upstream part of the basin (Fig. 2). The basin is characterised by a warm tropical savannah climate with an average temperature of about $23^{\circ} \mathrm{C}$. Five years of climatologic observations from June 1999 to May 2004 at 3 meteorological stations located in or near the Simiyu basin (Fig. 2) show distinctive wet and dry seasons. The wet season consists of 2 parts, i.e. a wet period with long rains from March to May and another wet period with short rains mainly in November, December and January. The total average annual precipitation varies between 700 and $1000 \mathrm{~mm}$, of which $39 \%$ occurs in the long rainy season from March to May, $41 \%$ in the short rainy season from November to January, and 20\% during the other months. Figure 3 shows the monthly variation of precipitation and potential evaporation in Simiyu basin from June 1999 to May 2004. Monthly potential evaporation in the basin was derived from observed pan evaporation in the climatologic stations and adjusted by a correction factor, which can vary from 0.5 to 0.85 (FAO, 1997), but is typically about two-thirds, i.e. 0.66, as used in this study. The resulting monthly potential evaporation values range from about $80 \mathrm{~mm}$ in the short rainy season to 140 $\mathrm{mm}$ in the dry season, yielding a total annual potential evaporation of about $1300 \mathrm{~mm}$.

No discharge measurements have been performed by the authorities, albeit river water levels have been recorded regularly since 1999, but the quality and reliability of this data is very poor. Hence, for this study, a flow gauging station was installed at the river outlet (Fig. 2), and water levels were recorded on a daily basis from June 2001 to May 2004. River discharge measurements were performed regularly using calibrated current meters, i.e. a type A OTT propeller V-Arkansas and a Global Water Flow Probe FP101. In total, 25 discharge measurements were conducted, which were more or less evenly distributed over a range of zero to about 230 $\mathrm{m}^{3} / \mathrm{s}$, corresponding to water heights of zero to about $4 \mathrm{~m}$. From these discharge and water level measurements, a rating curve was derived as described in the literature (Shaw, 1988; Chow et al., 1988).

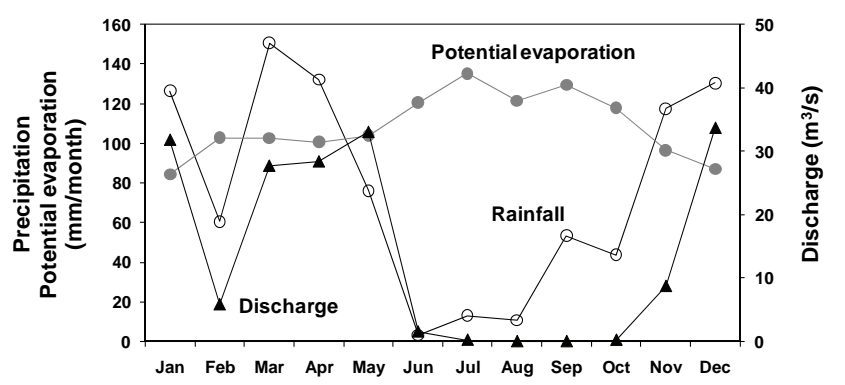

Figure 3

Variation of average monthly precipitation, potential evapotranspiration, and discharge at the basin outlet of the Simiyu River (1999-2004)

To cross check the rating curve, float method discharge measurements were performed as described by Wanielista et al. (1997), yielding a close match between observations and estimated discharge derived from the rating curve. With the rating curve, daily discharge values could be estimated from the recorded water level readings. The average monthly discharge at the basin outlet of Simiyu River for the period June 2001 to May 2004 is shown in Fig. 3. The mean monthly discharge ranges from zero to about $35 \mathrm{~m}^{3} / \mathrm{s}$. In the dry season, mainly from June to October, the discharge is very low or even nonexistent, while daily discharges of about $30 \mathrm{~m}^{3} / \mathrm{s}$ on average are recorded in the rainy seasons, with occasional peak flows of more than $100 \mathrm{~m}^{3} / \mathrm{s}$.

The 3 basic maps needed for running WetSpa were obtained as follows. A digital elevation model (DEM) was obtained by digitising topographical maps on scale 1:50 000 . A land-use map was obtained from satellite images (Landsat 7 ETM+) of 2001, with a resolution of $28.5 \mathrm{~m}$, using Idrisi32 Release 2 image-processing software and training sites for supervised classification (Rwetabula and De Smedt, 2005). A soil texture map was developed from the FAO world soil map (FAO, 2002), supplemented with field reconnaissance and information from literature (Meertens and Lupeja, 1996). All derived GIS data maps are raster based with $100 \mathrm{~m}$ grid size. Figure 4 shows the 3 basic maps of the Simiyu basin. The dominant land-use types are wasteland (mixed bare land and short grasses) (46.5\%), grassland (25.5\%), bushland (19.7\%), and cultivated land (8.3\%), while a very small (less than $1 \%$ ) area is covered by surface water. The soil texture classes are sandy loam $(63.8 \%)$, sandy clay loam (13.5\%), clay loam (12.9\%), clay (5\%), loam (2.9\%), and sandy clay $(1.9 \%)$. 
A
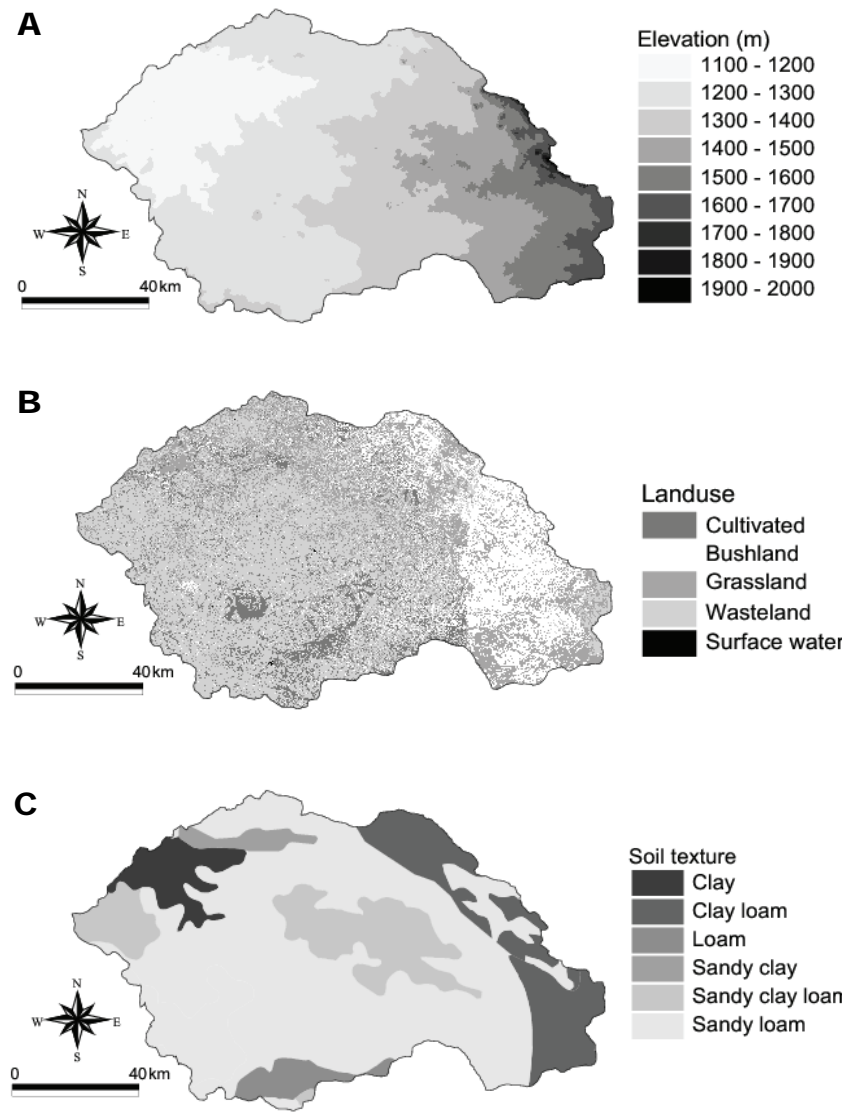

Soil texture

\section{Clay}

Clay loam

Loam

Sandy clay

Sandy clay loam

Sandy loam

Figure 4

Three basic GIS raster maps of the Simiyu basin needed for running WetSpa: (a) elevation, (b) land-use, and (c) soil texture

\section{Model application}

\section{Model input parameters}

Spatially-distributed model parameters are automatically derived from the topography, soil texture and land-use maps as shown in Fig. 1, using a database that is, by standard, available in the WetSpa model. All maps are in digital 100 m raster format. From the elevation map, hydrological features such as surface slope, flow direction, flow accumulation, stream network, stream order and sub-basins are delineated. The threshold for delineating the stream network is set to 100 pixels, meaning that a cell is considered to be drained by a stream when the upstream drained area becomes larger than $1 \mathrm{~km}^{2}$. From the river network, 199 sub-basins are identified with an average sub-basin area of about $54.3 \mathrm{~km}^{2}$. The calculated slope angles range from relatively flat to a maximum of $35.5 \%$ for the very steep slopes. Soil hydraulic conductivity, porosity, field capacity, plant wilting point, residual moisture content, and pore size distribution index for each grid cell are derived from the soil texture map. Similarly, root depth, interception storage capacity, and crop coefficient are derived from the land-use map. The hydraulic radius is derived by assuming an average hydraulic radius of $0.005 \mathrm{~m}$ for overland flow and interpolating between 1.0 to $4.3 \mathrm{~m}$ according to stream order for the river courses. The Manning roughness coefficient for overland flow is estimated based on land-use, using an attribute table provided in WetSpa. For the river channels, the Manning
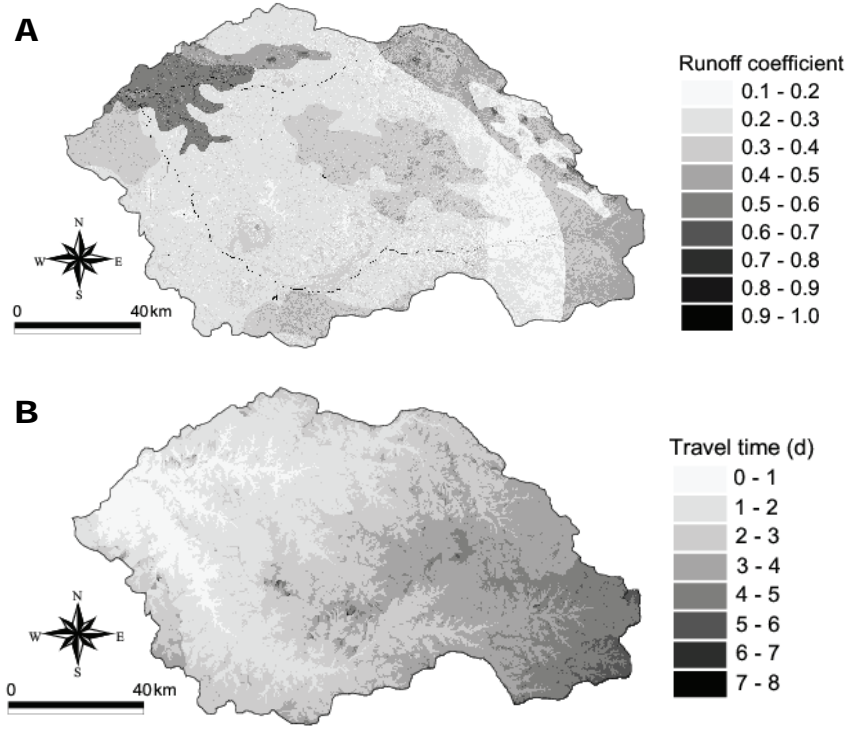

Figure 5

WetSpa model results: (a) spatial distribution of the potential runoff coefficient in the Simiyu basin, and (b) spatial distribution of the average flow time to the Simiyu basin outlet at Lake Victoria

roughness coefficient is linearly interpolated based on stream order with $0.075 \mathrm{~m}^{-1 / 3} \mathrm{~s}$ for the lowest order and $0.035 \mathrm{~m}^{1 / 3} \mathrm{~s}$ for the highest order. The potential runoff coefficient is determined from combinations of slope, soil type and land-use, using an attribute table provided in WetSpa (Liu and De Smedt, 2004a). Figure 5a shows the distribution of the potential runoff coefficient. As the basin is relatively flat, the potential runoff coefficient is strongly influenced by soil type and land-use. Potential runoff coefficients are higher in areas with clay soils and grass or bareland cover and lower in areas with sandy loam soils and bushland. On average, the potential runoff coefficient of the Simiyu basin is about 0.28 , which is a typical value for a relatively flat area with mixed cultivated or pasture/range land (Chow et al., 1988).

Maps of precipitation and potential evaporation are created based on the geographical location of each measuring station and the basin boundary using the Thiessen polygon method. The influence of altitude on precipitation was ignored, as no data are available to quantify such a relationship. Maps of flow velocity and mean and standard deviation of the travel time to the basin outlet are generated, by which the IUH of each grid cell to the basin outlet can be determined. Figure 5b shows the estimated average travel time from any interior location to the basin outlet. The travel time is 2.4 days on average and a maximum of about 8 days for the most remote areas in the east of the Serengeti game reserve.

\section{Model calibration}

The WetSpa model is run using the observed rainfall and potential evapotranspiration time series, and calibrated against daily stream-flow measurements at the basin outlet for the time period from June 2001 to May 2004. There are two sorts of parameters in WetSpa, i.e. spatially varying model parameters and fixed global model parameters. All spatial model parameters are automatically derived using GIS tools, as explained before. Global model parameters are time and space invariant 
Table 1

Calibration of the global WetSpa model parameters: description, symbol, units, preset feasible range, and estimated mean values and $95 \%$ confidence limits obtained with PEST

\begin{tabular}{|l|c|c|c|c|}
\hline Parameter description & Symbol & Units & Preset range & Calibration \\
\hline Runoff coefficient & $K_{r u n}$ & - & $0-5$ & $3.30 \pm 0.39$ \\
\hline Rainfall scaling factor & $P_{0}$ & $\mathrm{~mm} / \mathrm{d}$ & $0-1000$ & $1000 \pm 1556$ \\
\hline Evaporation correction factor & $K_{\rho p}$ & - & $0-2$ & $0.72 \pm 0.04$ \\
\hline Interflow scaling factor & $K_{i}$ & - & $0-15$ & $10.1 \pm 1.4$ \\
\hline Base flow recession constant & $K_{g}$ & $\mathrm{~d}^{-1}$ & $0-0.05$ & $(1.00 \pm 0.20) \times 10^{-5}$ \\
\hline
\end{tabular}

and are either adjustment coefficients or empirical constants that need to be preset by the user or can be calibrated when observations of stream-flow are available. Calibration is done using the Parameter ESTimation Tool (PEST) (Doherty and Johnston, 2003). In this automated calibration procedure, the best set of parameters is selected from within a reasonable range, by adjusting values until the discrepancies between observed and simulated hydrographs is reduced to a minimum in the weighted least squares sense. Prior to the automated calibration, an investigation of the parameter sensitivity is performed and the automated calibration is applied focusing only on the most sensitive parameters of the WetSpa model (Liu and De Smedt, 2004a; Bahremand and De Smedt, 2006), i.e. baseflow recession constant, initial soil moisture, interflow scaling factor, evaporation correction factor, and surface runoff parameters (runoff exponent and rainfall scaling factor).

The snowmelt parameters are not involved in the calibration process as the corresponding processes are irrelevant in the Simiyu basin. The global model parameters that should be calibrated are listed in Table 1.

The runoff coefficient, $K_{r u n}$, and the rainfall scaling factor, $P_{0}$, are used in Eq. (3) to express the influence of rainfall intensity on runoff generation by means of the $\alpha$-exponent of Eq. (2). Their preset ranges are 0 to 5 and 0 to $1000 \mathrm{~mm} / \mathrm{d}$, respectively. The evaporation correction factor, $K_{e p}$, is needed to adjust the potential evaporation data input to the model in Eq. (4). Its preset range is 0 to 2 . The interflow scaling factor, $K_{i}$, adjusts the hydraulic conductivity of the soil for calculation of interflow as expressed in Eq. (7), with a range of 0 to 15. The base flow recession constant, $K_{q}$, is needed to compute groundwater drainage as given in Eq. (8), with a preset range of 0 to $0.05 \mathrm{~d}^{-1}$. The last column of Table 1 gives the estimated values by calibration with PEST with the $95 \%$ confidence intervals. All parameters are well determined as the confidence intervals are small and the estimated mean values fall within the preset feasible range, except for the rainfall scaling factor which reaches the upper bound of the preset range and has a confidence interval that is larger than the estimated mean value. This indicates that the surface runoff does not depend upon the rainfall intensity. The runoff exponent, $\alpha$, in Eq. (3) is interpolated between the runoff coefficient, $K_{\text {run }}$, and 1 , depending upon the ratio of the rainfall intensity and the rainfall scaling factor, $P_{0}$. Because this ratio is very small, as the calibrated rainfall scaling factor, $P_{0}$, is equal to its preset maximum value, the $\alpha$-coefficient will always be very close to the runoff exponent, $K_{\text {run }}$. This means that the runoff strongly depends on the soil wetness, but not on the rainfall intensity. The value obtained for the evaporation correction factor indicates that the data derived from pan evaporation observations is not very accurate and needs to be adjusted by a factor 0.72 . This is not unexpected as evaporation pans do not necessarily respond to the same climatic variables as a vegetated surface
(FAO, 1997). The observed pan evaporation data was already adjusted by a correction factor of 0.66 , but present results suggest that for the Simiyu basin the correction factor for pan evaporation should rather be in the order of $0.66^{\prime} 0.72=0.47$, which is still within the range as suggested by FAO (1997).The interflow scaling factor is found to be rather large, which can be related to the soil texture and the effect of the vegetation, especially in the upstream part of the Simiyu basin. Most soils in the Simiyu basin are Planosols (FAO, 2002) characterised by an alluvial horizon with loamy sand or coarser textures, of which the lower boundary is marked within $100 \mathrm{~cm}$ from the surface by an abrupt textural change to a less permeable subsoil with significantly more clay material than the surface horizon (FAO, 2002). This explains some of the special conditions in the Simiyu basin. The sandy loam soils with a relatively high permeability would normally promote infiltration and groundwater recharge, but the less permeable subsoils promote stagnant soil water and subsequently more loss by evapotranspiration and interflow. In the WetSpa model these conditions are taken into account by means of a high interflow scaling factor, which leads to significant interflow.

The optimisation reveals that the baseflow recession coefficient is essentially zero, and consequently the WetSpa model predicts that there is no noticeable groundwater drainage to the Simiyu River. This corresponds to the actual situation as the Simiyu River is ephemeral, with stream flows mainly occurring only in the rainy season and no flow during dry periods.

\section{Results and discussion}

The simulated results are compared with daily observed discharge, both graphically and statistically for the period of observed river flows, i.e. 1 June 2001 to 31 May 2004. The predicted and observed hydrographs are presented in Fig. 6. Four hydrological model evaluation criteria are applied to assess the performance of the model (Hoffmann et al., 2004; De Smedt et al., 2005): (1) model bias, $M B$, or average error between observed and predicted discharge expressed as a fraction of the average observed discharge

$$
M B=\frac{\sum_{i=1}^{N}\left(Q_{s i}-Q_{o i}\right)}{\sum_{i=1}^{N} Q_{o i}}
$$

(2) Nash-Sutcliffe model efficiency, NS, (Nash and Sutcliffe, 1970), i.e. the ratio of the variance of the model bias and the observed flows

$$
N S=1-\frac{\sum_{i=1}^{N}\left(Q_{s i}-Q_{o i}\right)^{2}}{\sum_{i=1}^{N}\left(Q_{o i}-\overline{Q_{0}}\right)^{2}}
$$

(3) and (4) modified model efficiencies evaluating the ability of the model to reproduce the low flows, $L F$, and the high flows, $H F$, respectively. 


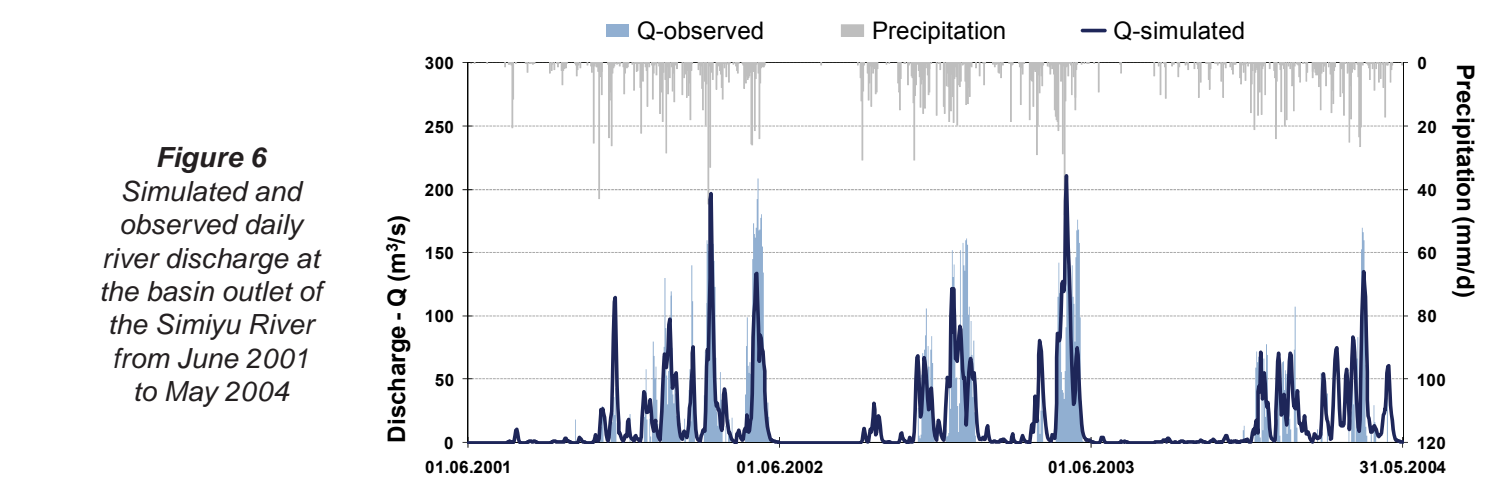

$$
\begin{aligned}
& L F=1-\frac{\sum_{i=1}^{N}\left(\ln Q_{s i}-\ln Q_{o i}\right)^{2}}{\sum_{i=1}^{N}\left(\ln Q_{o i}-\overline{\ln } Q_{o}\right)^{2}} \\
& H F=1-\frac{\sum_{i=1}^{N}\left(Q_{o i}+\bar{Q}_{0}\right)\left(Q_{s i}-Q_{o i}\right)^{2}}{\sum_{i=1}^{N}\left(Q_{o i}+\bar{Q}_{0}\right)\left(Q_{o i}-\bar{Q}_{o}\right)^{2}}
\end{aligned}
$$

where:

$Q_{s i}$ and $Q_{o i}$ are simulated and observed discharge at time step $i$,

$\bar{Q}_{0}$ is the mean observed discharge and

$\overline{\ln }_{0}$ is the the mean of the log-transformed discharge

$N$ is the total number of observations

The optimum value for $M B$ is 0 and for the other criteria this is 1 . The resulting model performances over the calibration period June 2001 to May 2004 are: 0.024 for the model bias, 0.57 for the Nash-Sutcliffe efficiency, and respectively 0.54 and 0.67 for the low and high flow efficiencies. These results show that the model performs satisfactorily, although in other studies (Liu et al., 2002; De Smedt et al., 2004) better results have been obtained with Nash-Sutcliffe efficiencies of 0.75 to 0.90 . The lower performance of the WetSpa model for the Simiyu basin is evidently caused by insufficient data about the spatial variation of rainfall and potential evaporation and the temporal variation of the discharge at the basin outlet.

As can be seen in Fig. 6, the river discharge, concentration time and flow volumes are reasonably predicted. The maximum recorded peak rainfall intensities amount to about $40 \mathrm{~mm} / \mathrm{d}$ and yield peak discharges of about $150 \mathrm{~m}^{3} / \mathrm{s}$. It appears that there are long periods of very small or even zero stream flow, indicating there is little or no baseflow in dry periods. The succession between wet and dry periods is well simulated suggesting that the model is able to reasonably capture the basic dynamics of the Simiyu River. Nevertheless, most observed discharges are not very accurately reproduced, likely due to insufficient spatial distribution of the rainfall gauging stations to accurately capture local rain events in this $10800 \mathrm{~km}^{2}$ basin. The required number of precipitation gauging stations per area (precipitation gauge density) for a good evaluation of the spatial distribution of precipitation is discussed by Shaw (1988) and Wanielista et al. (1997).The minimum density of the precipitation stations in flat areas, as reported by Shaw (1988), ranges from 600 to 900 $\mathrm{km}^{2}$ per gauge. Therefore, at least 10 stations are needed for a large basin such as that of the Simiyu River, while at present there are only 3 stations, of which only one is located inside the basin (Fig. 2). Also, the discharge estimated from the daily water level recordings cannot capture all temporal flow variations, especially flash floods. Hourly or half-hourly recordings are needed to accurately monitor flood hydrographs of short duration. Another source of error could be runoff retained by intermediate storage in the basin, a process that is not included in the WetSpa model.

After calibration, the model is applied for a longer period, because the dynamics of the hydrological processes in the basin can change significantly over long periods of time in response to the variability of the rainfall from year to year. Hence, keeping the same calibrated parameters, the model was used to simulate discharge at the basin outlet for a 5 -year period from

\begin{tabular}{|c|c|c|c|c|}
\hline \multicolumn{5}{|c|}{$\begin{array}{l}\text { Table } 2 \\
\text { Estimated average annual water balance components of } \\
\text { the Simiyu basin for a 5-year period, June } 1999 \text { to May } \\
\text { 2004, and estimated daily mean and maximum values for } \\
\text { the 5-year period }\end{array}$} \\
\hline \multirow[t]{2}{*}{ Component } & \multicolumn{2}{|c|}{ Simulated } & \multirow{2}{*}{$\begin{array}{c}\text { Mean } \\
(\mathrm{mm} / \mathrm{d})\end{array}$} & \multirow{2}{*}{$\begin{array}{c}\operatorname{Max} \\
(\mathrm{mm} / \mathrm{d})\end{array}$} \\
\hline & $(\mathrm{mm} / \mathrm{y})$ & (\%) & & \\
\hline Precipitation & 849 & 100.0 & 2.32 & 47.9 \\
\hline Interception & 50 & 5.9 & 0.14 & 1.1 \\
\hline Surface runoff & 17 & 2.0 & 0.05 & 1.9 \\
\hline Infiltration & 782 & 92.1 & 2.13 & 44.8 \\
\hline Evapotranspiration & 776 & 91.4 & 2.12 & 11.7 \\
\hline Interflow & 27 & 3.2 & 0.08 & 1.3 \\
\hline Groundwater recharge & 330 & 38.8 & 0.90 & 1.3 \\
\hline Groundwater drainage & 0 & 0.0 & 0.00 & 0.0 \\
\hline Total discharge & 44 & 5.2 & 0.12 & 2.5 \\
\hline Soil moisture storage & +4 & 0.5 & - & - \\
\hline Groundwater storage & +25 & 3.0 & - & - \\
\hline
\end{tabular}
June 1999 to May 2004.

Table 2 shows the estimated mean annual water balance for the 5-year period.

The percentages in this table relate to the mean annual precipitation. Also shown in the table are daily mean and maximum values over the 5 -year period. The annual water balance is also depicted schematically in Fig. 7, where the different components that make up the evapotranspiration are represented separately for clarification. The mean annual precipitation of $849 \mathrm{~mm} / \mathrm{y}$ is partitioned between surface runoff, interception, and infiltration, i.e., 17,50 and $782 \mathrm{~mm} / \mathrm{y}$, respectively, representing 2.0\%, $5.9 \%$ and $92.1 \%$ of the total precipitation. The amount intercepted is assumed to be lost by evaporation. From the soil, $330 \mathrm{~mm} / \mathrm{y}(38.8 \%)$ percolates downward to recharge the groundwater, and $421 \mathrm{~mm} / \mathrm{y}(49.6 \%)$ is lost by evapotranspiration and $27 \mathrm{~mm} / \mathrm{y}(3.2 \%)$ by interflow. The sum of percolation, soil evapotranspiration and interflow is not exactly equal to the infiltration, because the model predicts that there is a net increase of the soil moisture storage of $4 \mathrm{~mm} / \mathrm{y}(0.5 \%)$. 


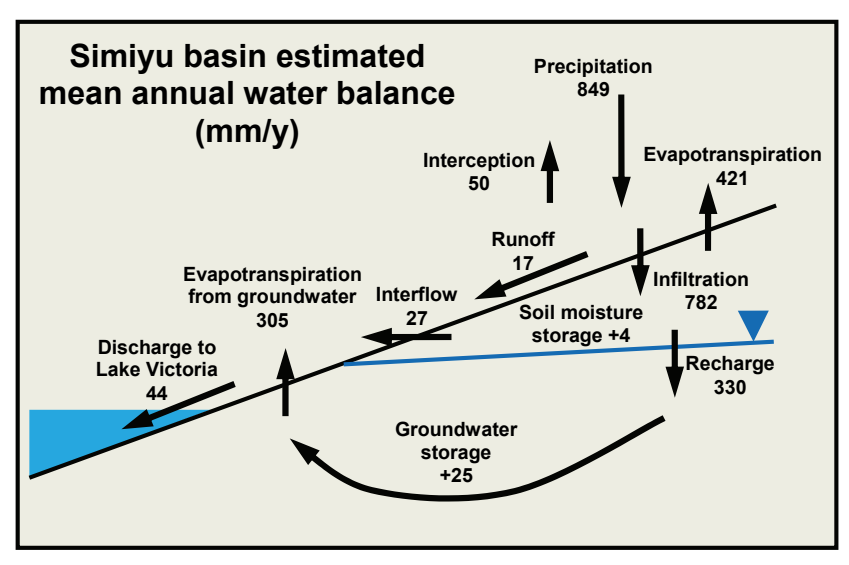

Figure 7

Estimated average annual water balance of the Simiyu basin for a 5-year period from June 1999 to May 2004; numbers represent fluxes in $\mathrm{mm} / \mathrm{y}$

This is clearly a temporal effect because there cannot be a continuous increase in soil moisture storage. Inspection of the rainfall series reveals that the first 2 years (1999-2000) are rather dry, while the last 3 years (2001-2003) are rather wet. Hence, after the dry years 1999 and 2000 soil moisture storage gradually increases during the wetter years 2001 and 2003. Very likely this will be reversed in the future by the occurrence of dry periods. Similarly, there is an annual average net increase in the groundwater storage of $25 \mathrm{~mm} / \mathrm{y}$ (3.2\%), while the model predicts that there is no groundwater drainage to the Simiyu River, but groundwater is lost by evapotranspiration from the groundwater reservoir by an amount of $305 \mathrm{~mm} / \mathrm{y}$ $(35.9 \%)$. Hence, there is considerable groundwater recharge but no appreciable base flow in the Simiyu River, as is also observed in the field during drier periods when the river runs dry. Very likely, groundwater is drained to seepage areas in depressions, where, due to the high evaporative demand of the atmosphere, water is evaporated from the soil or taken up and transpired by phreatophytic vegetation before it can contribute to river base flow. Several of such wetlands occur along the shores of Lake Victoria (Hongo and Masikini, 2003).

The estimated annual discharge to Lake Victoria is 44 $\mathrm{mm} / \mathrm{y}$, which corresponds to a flow volume of about $475 \times 10^{6}$ $\mathrm{m}^{3}$ per year. The discharge consists only of surface runoff and interflow, i.e., 17 and $27 \mathrm{~mm} / \mathrm{y}$, respectively, which represent $38.6 \%$ and $61.4 \%$ of the total discharge. The modest surface runoff can be explained by the relatively flat topography and the mixed cultivated or pasture soil cover in addition to the usually very dry soils that promote infiltration instead of runoff. The relatively large interflow may be due to the Planosols covering a large part of the basin, and the zero groundwater drainage is likely due to the high evaporative demand of the atmosphere. Overall, the discharge amounts to only about $5.2 \%$ of the precipitation, while the model predicts that $91.4 \%$ of the total precipitation is lost by evapotranspiration, including loss due to interception, soil evaporation, plant transpiration and evaporation losses from the groundwater reservoir.

The total runoff contributed by each land-use type is obtained by integration of the surface runoff and interflow from each grid cell belonging to a particular land use type within the basin over the simulation period. Estimated average runoff volumes contributed by each land-use type are: $8.7 \%$ for cultivated land, $48.7 \%$ for wasteland (short grasses and bare land), $28.7 \%$ for grassland, $13.4 \%$ for bushland and $0.5 \%$ for surface water. The runoff volume originating from mixed short grasses and bare land is quite high because these occupy the largest portion of the basin area (46.4\%). As such, agricultural land, which is the primary source for non-point pollution and degradation of Lake Victoria, contributes to about $9 \%$ of the Simiyu River discharge. This corresponds to an annual volume of water of about $43 \times 10^{6} \mathrm{~m}^{3}$ which may contain and transport agrochemical residues to Lake Victoria.

\section{Conclusions}

A spatially-distributed hydrologic simulation model (WetSpa) on a daily time scale was applied to the Simiyu River basin, a tributary of Lake Victoria, Tanzania. The model uses spatial elevation, land-use and soil data in GIS form, and observed climatologic time series, to predict river discharge. The model performance over the 4 -year verification period results in a model bias of $2.4 \%$, while the model efficiency for reproducing the river discharge is $57.4 \%$. This suggests that the model can reasonably estimate the water balance and overall hydrological behaviour of the Simiyu basin, but is less accurate in reproducing daily flows. The model performance would likely improve with more accurate and higher resolution datasets of topography, land-use and soil type, but the main constraint remains the sparseness of the rainfall stations and the lack of precise discharge observations at the basin outlet. The density of rainfall and river gauging stations and their geographic distribution seems to be a major constraint in developing countries around the world and greatly affects the accuracy of model predictions. A viable option for rainfall data would be satellite rainfall estimates (RFE) that have better spatial and temporal resolution.

The model-predicted travel time of the runoff to the outlet of the basin at Lake Victoria is about 2.4 days on average and maximum 8 days from the remote areas as the Serengeti national park/game reserve. River discharge only amounts to $5.2 \%$ of the total precipitation, while the remainder is lost by evapotranspiration or temporarily stored in the soil or groundwater reservoir. The river discharge consists mainly of runoff (38.6\%) and interflow (61.4\%), while there appears to be negligible base flow due to drainage of groundwater. This agrees with the ephemeral nature of the river as experienced in the field. The low runoff can be explained by the relatively flat topography and the dryness of the soils which occurs for most of the time. The relatively high contribution of the interflow may be explained by the presence of Planosols covering $63.8 \%$ of the basin area. The absence of base flow is probably due to the high evaporative demand of the atmosphere, such that groundwater seepage is lost by evaporation or transpiration by phreatophytic vegetation before it can contribute to river flow. The total annual flow to Lake Victoria produced by the Simiyu River is about $475 \times 10^{6} \mathrm{~m}^{3}$, of which $9 \%$ originates from agricultural land, and occurs mainly in the wet seasons, from March to May and from November to January.

The WetSpa model can be used to estimate the annual water balance components in the Simiyu basin. Such information can consequently be linked to water quality models to estimate the contaminant loads generated from the agricultural fields in the Simiyu basin and which are transported to and deposited in Lake Victoria. Also, the results of this study can be used to simulate flows in ungauged sub-basins or in neighbouring similar basins to study the effects of topography, soil type, and land-use on hydrological behaviour.

Although the Simiyu basin is relatively flat, there is a need 
for establishing more and sustainable climatologic stations. Also, more detailed river discharge measurements are needed to improve the model calibration and predictions.

\section{Acknowledgements}

The authors are very grateful to the Lake Victoria Environmental Management World Bank Project (LVEMP) for their support of this research. The authors would also like to thank two anonymous reviewers for their suggestions to improve the paper.

\section{References}

BAHREMAND A, CORLUY J, LIU Y, and DE SMEDT F (2005) Stream flow simulation by WetSpa model in Hornad river basin, Slovakia. In: Van Alphen J, Van Beek E and Taal M (eds.) Floods from Defence to Management. Taylor-Francis Group, London. 67-74.

BAHREMAND A and DE SMEDT F (2006) Sensitivity and uncertainty analysis of a GIS-based flood simulation model using PEST. WSEAS Trans. Environ. Dev. 2 (1) 29-37.

BROWNE FX (1990) Stormwater management. In: Corbitt RA (ed.) Standard Handbook of Environmental Engineering. McGraw-Hill, New York. 7.1-7.135.

CHOW VT, MAIDMENT DR and MAYS LW (1988) Applied Hydrology. McGraw Hill Inc., New York.

CRUL RCM (1995) Limnology and hydrology of Lake Victoria: comprehensive and comparative study of great lakes. UNESCO/ IHP - IV Project M-5.1, France.

DE SMEDT F, LIU YB and GEBREMESKEL S (2000) Hydrologic modeling on a basin scale using GIS, and remote sensed land-use information. In: Brebbia CA. (ed.) Risk Analysis II. WTI Press, Southampton, Boston. 3061-3078.

DE SMEDT F, LIU Y B, GEBREMESKEL S, HOFFMANN L and PFISTER L (2004) Application of GIS and remote sensing in flood modelling for complex terrain: GIS and Remote Sensing in Hydrology, Water Resources and Environment. In: Chen YB, Takara K, Cluckie I and De Smedt F. (eds.) IAHS Publ. 289 23-32.

DE SMEDT F, LIU YB and GEBREMESKEL S (2005) Integrated modelling of hydrological processes on basin scale. In: Arijs E and Ducarme B (eds.) Proc. Geodesy and Geophysics for the Third Millennium, 13 October 2005, Brussels. 51-67.

DOHERTY J and JOHNSTON JM (2003) Methodologies for calibration and predictive analysis of a watershed model. J. Am. Water Resour. Assoc. 39 251-265.

DUNNE T (1978) Field studies of hill slope flow processes. In: Kirkby MJ (ed.) Hill Slope Hydrology. John Wiley and Sons, Chichester. 227-294.

EAGLESON PS (1978) Climate, soil, and vegetation, a simplified model of soil moisture movement in liquid phase. Water Resour. Res. 14 (5) 722-730.

FAO (2002) Major Soils of the World. FAO Land and Water Digital Media Series No. 19. FAO, Rome.

FAO (1997) Small-scale irrigation for arid zones: principles and options. FAO Natural Resources and Environment Department. URL: http://www.fao.org/docrep/w3094e/w3094e00.htm (Accessed 2004).

FAMIGLIETTI JS and WOOD EF (1994) Multiscale modeling of spatially variable water and energy balance processes. Water Resour. Res. 30 (11) 3061-3078.

GEBREMESKEL S, LIU YB, DE SMEDT F and PFISTER L (2005) Analyzing the effect of climate changes on stream flow using statistically downscaled GCM scenarios. Int. J. River Basin Manage. 3 (1) 1-10.

HENDERSON FM (1996) Open Channel Flow. McMillan, New York, USA.

HENRY L and KISHIMBA MA (2003) Levels of pesticides residues in water, soil and sediments from southern Lake Victoria and its basin, Tanzania. J. Sci. 29 (1) 77-90.
HOFFMANN L, EL IDRISSI A, PFISTER L, HINGRAY B, GUEX F, MUSY A, HUMBERT J, DROGUE G and LEVIANDIER T (2004) Development of regionalized hydrological models in an area with short hydrological observation series. River Res. Appl. 20 (3) 243-254.

HONGO H and MASIKINI M (2003) Impact of immigrant pastoral herds to fringing wetlands of Lake Victoria in Magu district Mwanza region, Tanzania. Phys. Chem. Earth 28 1001-1007.

JOLANKAI G, PANUSKA J and RAST W (1999) Modelling of nonpoint source pollutant loads. In: Thornton JA, Rast W, Holland MM, Jolankai G and Ryding S-O (eds.) Assessment and Control of Nonpoint Sources Pollution of Aquatic Ecosystems. UNESCO, Paris, France.

LIU Y B, DE SMEDT F and PFISTER L (2002) Flood prediction with the WetSpa model on basin scale. In: Wu BS, Wang ZY, Wang Q, Huanga GH, Fang W and Huang JC (ed.) Flood Defence. Science Press, New York. 499-507.

LIU Y B, GEBREMESKEL S, DE SMEDT F, HOFFMANN L and PFISTER L (2003) A diffusive transport approach for flow routing in GIS-based flood modelling. J. Hydrol. 38 (1-4) 91-106.

LIU Y B and DE SMEDT F (2004a) WetSpa Extension, Documentation and User Manual. Department of Hydrology and Hydraulic Engineering, Vrije Universiteit Brussel, Belgium.

LIU Y B and DE SMEDT F (2004b) Flood modeling for complex terrain using GIS and remote sensed information. Water Resour. Manage. 19 605-624.

LIU Y B, BATELAAN O, DE SMEDT F, HUONG NT and TAM VT (2005) A test of a distributed modelling approach to predict flood flows in the karst Suoimuoi basin in Vietnam. Environ. Geol. 48 931-940.

LIU Y B, CORLUY J, BAHREMAND A, DE SMEDT F, POOROVA $J$ and VELCICKA L (2006) Simulation of runoff and phosphorus transport in a Carpathian basin, Slovakia. J. River Res. Appl. 22 1009-1022.

LUGOMELA C and MACHIWA J (2002) Nutrient distribution, phytoplankton abundance and species composition in Magu bay following the principal rain season in 2001. In: Machiwa JF (ed.) Nutrients, Micro-Algae, Sedimentation and Sediment Associations at the Mouth of Simiyu River (Magu Bay of Speke Gulf) Lake Victoria, Tanzania. Lake Victoria Environmental Management Project (LVEMP), Tanzania.

MALLANTS D and FEYEN J (1994) Kwantitatieve en kwalitatieve aspecten van oppervlakte- en grondwaterstroming (in Dutch). ACCO Leuven, Belgium.

MEERTENS HCC and LUPEJA PM (1996) A collection of agricultural background information for Mwanza region. Kilimo/FAO Plant Nutrition Programme in Tanzania. Field document No. GCPF/ URT/106/NET, Mwanza, Tanzania.

NASH JE and SUTCLIFFE JV (1970) River flow forecasting through conceptual model. J. Hydrol. 10 282-290.

NINGU J (2000) An inventory of agro-chemicals in the Lake Victoria basin, Mwanza, Tanzania. Lake Victoria Environmental Management Project (LVEMP), Tanzania.

NURMOHAMED R, NAIPAL S and DE SMEDT F (2006) Hydrologic modeling of the Upper Suriname River basin using WetSpa and ArcView GIS. J. Spat. Hydrol. 6 (1) 1-17.

PHOON S Y, SHAMSELDIN AY and VAIRAVAMOORTHY K (2004) Assessing impacts of climate change on Lake Victoria Basin, Africa. Proc. 30 ${ }^{\text {th }}$ WEDC International Conference, 25-29 October, 2004, Vientiane, Lao PDR. 392-397.

RWETABULA J, DE SMEDT F, REBHUN M and MWANUZI F (2006) Transport of micropollutants and phosphates in the Simiyu River (tributary Lake Victoria), Tanzania. In: Lyon WG, Hong J and Reddy RK (eds.) Proceedings of $1^{\text {st }}$ International Conference on Environmental Science and Technology, USA. American Science Press, New Orleans, USA. 110-116.

RWETABULA J and DE SMEDT F (2005) Land-use and land cover mapping of the Simiyu Basin (Tanzania) using remote sensing techniques. Proc. FIG Working Week and $8^{\text {th }}$ International Conference of Global Spatial Data Infrastructure (GSDI-8), 1621 April,2005, Cairo, Egypt. URL: http:/www.fig.net/cairo/index. $\underline{\mathrm{htm}}$. 
SCHEREN PAGM, ZANTING HA and LEMMENS AMC (2000)

Estimation of water pollution sources in Lake Victoria, East Africa: Application and elaboration of the rapid assessment methodology. J. Environ. Manage. 58 235-248.

SHAW EM (1988) Hydrology in Practice. Van Nostrand Reinhold (International) Co. Ltd., London, UK.

THORNTHWAITE CW and MATHER JR (1955) The Water Balance. Laboratory of Climatology, Publ. No. 8, Centerton NJ.
WANG Z, BATELAAN O and DE SMEDT F (1996) A distributed model for Water and Energy Transfer between Soil, Plants and Atmosphere (WetSpa). Phys. Chem. Earth 21 (3) 189-193.

WANIELISTA M, KERSTEN R and EAGLIN R (1997) Hydrology: Water Quantity and Quality Control. John Wiley and Sons, New York.

WITTENBERG H (1999) Base flow recession and recharge as nonlinear storage processes. Hydrol. Proc. 13 715-726. 